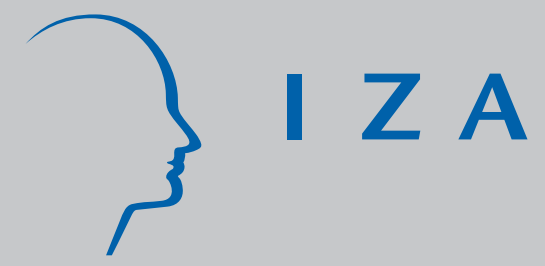

IZA DP No. 5336

ICT Skills and Employment: A Randomized Experiment

Mariana Blanco

Florencia Lopez Boo

November 2010

Forschungsinstitut zur Zukunft der Arbeit Institute for the Study of Labor 


\title{
ICT Skills and Employment: A Randomized Experiment
}

\author{
Mariana Blanco \\ El Rosario University \\ Florencia Lopez Boo \\ Inter-American Development Bank \\ and IZA
}

\section{Discussion Paper No. 5336 \\ November 2010}

\author{
IZA \\ P.O. Box 7240 \\ 53072 Bonn \\ Germany \\ Phone: +49-228-3894-0 \\ Fax: +49-228-3894-180 \\ E-mail: iza@iza.org
}

\begin{abstract}
Any opinions expressed here are those of the author(s) and not those of IZA. Research published in this series may include views on policy, but the institute itself takes no institutional policy positions.

The Institute for the Study of Labor (IZA) in Bonn is a local and virtual international research center and a place of communication between science, politics and business. IZA is an independent nonprofit organization supported by Deutsche Post Foundation. The center is associated with the University of Bonn and offers a stimulating research environment through its international network, workshops and conferences, data service, project support, research visits and doctoral program. IZA engages in (i) original and internationally competitive research in all fields of labor economics, (ii) development of policy concepts, and (iii) dissemination of research results and concepts to the interested public.
\end{abstract}

IZA Discussion Papers often represent preliminary work and are circulated to encourage discussion. Citation of such a paper should account for its provisional character. A revised version may be available directly from the author. 
IZA Discussion Paper No. 5336

November 2010

\section{ABSTRACT \\ ICT Skills and Employment: A Randomized Experiment ${ }^{\star}$}

The aim of this paper is to evaluate the impact that the acquisition of Information and Communication Technologies (ICT) skills has on the labor market of two Latin-American cities: Buenos Aires and Bogota. Using cross-sectional data from an experiment that randomly assigned the ICT skills line in the resume, we assess the returns to ICT skills. For that, we submit approximately 11,000 fictitious Curricula Vitae (CVs) for real job vacancies published daily in the main job search engines in both cities. We estimate a binary choice model to identify differences in callbacks depending on ICT skills. We also analyze how gender, place of residence and occupational categories interact with ICT skills. Our econometric analysis supports previous literature suggesting that ICT skills could increase the probabilities of inclusion in the labor market, mainly for those at some level of disadvantage. To the best of our knowledge, this is the first study that quantifies the effect of ICT skills on employment. Our findings suggest that having ICT skills in the resume can increase the probability of receiving a callback by around 1 percent or more. This effect is much stronger in Bogota than in Buenos Aires, which suggests that ICT could be acting differently depending on the characteristics of the labor market.

JEL Classification: J23, J24

Keywords: Information and Communication Technologies, hiring decisions, labor demand

Corresponding author:

Florencia Lopez Boo

Inter-American Development Bank

1300 New York Avenue, N.W.

Washington, DC 20577

USA

E-mail: florencial@iadb.org

\footnotetext{
* The authors wish to thank Alberto Chong and Matias Busso for interesting discussions in an earlier stage of the paper. Julián Aramburu, Iva Trako, Jaime Sarmiento and Angela Amaya provided excellent research assistance.
} 


\section{Introduction}

Over the last decade, Information and Communication Technologies (ICTs hereafter) have been widely acknowledged as essential resources for socioeconomic development. In the information and globalization era, ICTs provide developing nations with an unprecedented opportunity to meet vital development goals, such as poverty reduction, basic healthcare, education, and democratic enhancement, among others.

Additionally, acquisition of ICTs skills, both at a country and individual level, can boost the inclusion of marginalized groups. This inclusion can happen through different channels, such as improving these groups participation in democratic processes (otherwise inaccessible for them); providing them with basic healthcare and better life conditions, allowing them to participate in the labor market, etc.

This paper focuses particularly on labor market's outcomes. It is well known that basic ICT skills can play a relevant role in increasing employability. ${ }^{1}$ People can be excluded from consideration for employment just by virtue of not being able to demonstrate basic ICT knowledge. In this case, no amount of effort to conduct an online job search, write a resume, or receive assistance in other areas will make a noticeable difference. Thus, ICT skills might be often a gateway that enables the possibility of employment.

Consequently, the aim of this paper is to evaluate the impact that the acquisition of these ICT skills has on the employability of jobseekers in two important Latin-American cities. Specifically, we study whether stating high ICT skills in the sent resume increases the probability of receiving a callback afterwards. Our experimental design allows us to assess the returns of ICT skills in terms of increasing employability.

As in the education literature, identifying the unbiased effect of having a certain skill is a non trivial task. The estimated effect could be contaminated by endogeneity and/or unobservable heterogeneity. The empirical literature deals with this problem using two alternative methodologies: regression analysis (and in the education literature generally using instrumental variables) and natural experiments. ${ }^{2}$

In the labor market literature, this identification problem is mainly due to the difficulties associated with observing the full set of relevant variables determining individual's labor market productivity. In most cases, the analysts would have access to a limited

\footnotetext{
${ }^{1}$ There is currently no commonly adopted definition of ICT skills, but efforts are ongoing to characterize the various types of ICT skills, for example through the European e-Skills Forum (2004). Three categories of ICT competencies are distinguished: (1) ICT specialists: who have the ability to develop, operate and maintain ICT systems. In this case, ICTs constitute the main part of their job; they develop and put in place the ICT tools for others. (2) Advanced users: competent users of advanced, and often sector-specific, software tools. Here, ICTs are not the main job but a tool; and (3) Basic users: competent users of generic tools (e.g. Word, Excel, Outlook, PowerPoint) needed for the information society, e-government and working life. Here too ICTs are a tool, not the main job (OECD, 2005). In this paper, basic ICT skills are defined as those needed to perform common tasks associated with (almost) any clerical-type of job, as in definition (3).

${ }^{2}$ See Altonji and Blank, 1999, Blank and Citro, 2004) for complete surveys on the econometric problems related to the identification of discrimination in the labor market using regression analysis and field experiments.
} 
set of individuals' observed characteristics. Information on skill levels, school and family environments, are usually not available. Furthermore, even after collecting a comprehensive set of variables, the results from this approach would still need to be shown robust to the presence of unobserved heterogeneity in the population.

In this sense, with an experimental strategy we could accurately identify the effect of possessing a certain skills on a predefined labor market outcome. This approach has received increasing attention for its capacity to remediate some of the limitations associated with the conventional regression analysis approach. ${ }^{3}$

A new approach uses experiments in which fake curriculum vitae were sent in response to real announcements Bertrand and Mullainathan (2004); Bravo et al. (2008).

This paper follows the recent literature of experimental studies, better illustrated by the line of work developed by Bertrand and Mullainathan (2004). They measured racial discrimination in the labor market, by posting fictitious curriculum vitae for job vacancies published in Boston and Chicago newspapers and monitoring the call back rate of each CV sent.

They found that CVs associated with white names received $50 \%$ more calls for an interview than those with African-American names. Additionally, the authors find some evidence that employers were inferring social class based on applicants' names. We are aware of only one study for a developing country, Chile, that finds that both gender and neighborhood are determinants of call back rates Bravo et al. (2008).

We fully explore and follow the spirit of this procedure in order to evaluate the impact ICTs have in the labor market. Our experiment consists on sending fictitious CVs to real job vacancies. Every variable included in these CVs are controlled for similarity, except the sex and the ICTs skills level of each applicant. After sending the CVs, it is measured whether the number of callbacks or e-mails for future interviews received by the ICT-skilled applicant is significantly different from those received by the ICT-unskilled applicants.

Moreover, our approach improves the experimental design utilized by Bertrand and Mullainathan (2004). We construct equally qualified CVs and then assigned names, gender, and ICTs skills, among other variables. Bertrand and Mullainathan (2004) on the contrary, based their analysis on a sample of real CVs and assigned to each of them names identified with a particular race, respecting the share of whites and blacks in the population. The differences between the two approaches have at least one important implication. By generating completely new and fake CVs we can control for different individual characteristics. However, we acknowledge the fact that some of our fictitious

\footnotetext{
${ }^{3}$ Experimental approaches can be divided into two types: audit studies and natural experiments. The latter take advantage of unexpected changes in policies or events (Levitt, 2004; Antonovics and Walsh, 2004, 2005; Goldin and Rouse, 2000; Newmark and Nort, 1996). Audit studies on the other hand, use either the personal approach strategy, which sends individuals to job interviews or undertakes job applications over the telephone, or the strategy of sending written applications for real job vacancies. The first procedure has been criticized by arguing that it is impossible to ensure that false applicants are identical except for the characteristics of interest. Also, testers were sometimes warned that they were involved in a study, and their behavior could bias the results Riach and Rich (2002); Siegelman and Heckman (1993); Heckman (1998)
} 
CVs may appear 'too good to be true', so our applicants could be subject to positive discrimination. Nevertheless, our careful experimental design (including the creation of the fake $\mathrm{CVs}$ ) should prevent our results from being contaminated by this potential bias.

To the best of our knowledge, this paper constitutes the first attempt to rigorously study the effect of ICT skills on the probability of employment, both in Latin America and elsewhere.

While numerous studies have documented the effects on labor market outcomes for high-end ICT skills (programmers and other IT specialists), surprisingly little research has been conducted on basic ICT skills, especially in a developing country (Roodt and Paterson, 2008). The evidence on ICT skills and employment is scant and in general does not use representative micro-data. For instance, (Lpez-Bassols, 2002) found a positive effect of ICT training on employment and economic growth using aggregate-national level data; while (Chapple, 2006) interviewed graduates from ICT training programs offered by several NGOs in the United States to conclude that, in most cases, the training was successful in helping them find and retain jobs for at least three years. In a developing country context, Walton et al (2009) examine the role of ICT skills on employability in Kazakhstan and find that, while ICT skills can be a predictor of employment and higher income, the levels of ICT skills required to obtain these jobs are not as high as one may expect. They argue that what are perceived as basic ICT skills in a developed nation are considered sophisticated skills in developing countries and transitional economies.

In terms of the wages-ICT relationship, the evidence also shows a positive correlation (David Castillo and Valls, 2008; Karen Mossberger and McNeal, 2008). For LatinAmerica the evidence is scarce, maybe due to the lack of micro-data on the variable of interest. For example, Jacinto and Lusquios (2007) evaluated the effects of a Latin American ICT training program and found that the employment held by the graduates of this program was, in relative terms, of higher quality than that held by individuals of similar age and social status who did not have ICT training. Moreover, Silvero (2006) finds that a better access to ICTs increases the labor income of the individuals in Paraguay, Hernn Ruffo and Brassiolo (2006) show that lower educated workers benefit more (in terms of wage differentials) from the use of (Personal Computers) PCs in Argentina.

Using original experimental data from Buenos Aires and Bogotá, which contains a cross-sectional sample of approximately 11,000 observations of CVs sent to two occupational categories (Administration/Accountancy and Sales/Commercial), we found that stating high ICT skills on the CV, significantly increases the likelihood of being call for a job interview. A simple descriptive analysis of our data and also our formal econometric estimations seem to suggest that having basic knowledge of informatics tools could generate higher employment opportunities of the order of $1 \%$, after controlling by an important set of covariates.

The paper is organized as follows. Section 2 describes the experiment design applied to this investigation. Section 3 presents the data and statistics, Section 4 presents the main results of the paper, and Section 5 concludes. 


\section{Experimental Design}

The first step of the experimental design is to generate fictitious CVs for real job vacancies published weekly in top job search web sites in each city. The challenge is to produce a set of realistic and representative resumes without effectively using resumes that belong to actual jobseekers. To achieve this goal, we created a CV template for each city. The template had to represent the average actual jobseeker for each of the occupational categories that were considered in the study but we altered them sufficiently to create distinct resumes. Therefore, we begin by performing an additional study of the CVs posted by jobseekers in one job search engine for both cities and we created a dataset of CVs corresponding to the main occupational categories as the basis for our artificial resumes. It is worth noting that this study was conducted in both cities independently. That is, the Buenos Aires' CV template and database were created using the CVs posted by jobseekers in Buenos Aires and the template and database for Bogotá were developed using the CVs posted by jobseekers in Bogotá. Additionally, one template was created for each of the four occupational categories considered in the study. While the resumes posted in this web site may not be completely representative of the average job seeker, they provide a practical approximation (See Appendix A and C). ${ }^{4}$

We only included the CVs of people seeking employment in the two cities under analysis, Buenos Aires and Bogotá. ${ }^{5}$ We also restrict our analysis to two occupational categories, as per the type of jobs that are expected to require the use of ICT skills: Sales/Commercial and Administrative/Accountancy. ${ }^{6}$

Finally, we only consider two educational categories that belong to the so-called 'semi-skilled' sub-category: high school and undergraduate ongoing. Professionals (such as lawyers, doctors, engineers) were left out of the analysis as they compete in a different labor market. Since they are supposed to have at least a medium level of ICT skills, the skills relevant for the job application are other than those of this study such as foreign languages, experience in the field of interest, etc. On the other hand, low skilled workers (less than high school education) are not required to have ICT skills to perform their daily job activities. Therefore, they are also irrelevant for this study.

\subsection{Defining Information and Communication Technologies (ICTs) Skills}

Given the main interest of the study, we defined two variables of interest that were taking into account when producing the fictitious CVs. The first variable is ICT skills, that was set either as High or Low ICT skills, while the second is Gender. These two will define four demographic cells for our experiment.

The definition of the variable ICT skills is a crucial one for our experimental design.

\footnotetext{
${ }^{4}$ All Appendices are available upon request.

${ }^{5}$ Given that the City of Buenos Aires (Capital Federal) is very well integrated with the suburbs in terms of geography, transport, media, information, etc; both the city and the suburbs were included in the experiment. However, in Bogotá, the suburbs are not as well-integrated something that translates to the labor market itself; that is why we only took the City of Bogotá as the unit of interest.

${ }^{6}$ In Table A.1 of Appendix A we present a list of occupations within these categories in both cities.
} 
For the 'Low ICT Skills CVs', in the Computer Skills section, we selected only Office Tools with Basic knowledge (among the options of Basic, Medium and Advanced). In the description window we wrote: Basic Knowledge of PC.

On the other hand, for the 'High ICT Skills CVs' we stated Advance knowledge of Office Tools, while in the description windows for Office Tools we listed: Word, Excel, PowerPoint, Outlook, Internet. Additionally, if the ad required Management Software, Database Software or Operative System we stated Advance knowledge in the corresponding category. Moreover, in the description window we listed softwares which were specific to the occupational category and country. For Administration/Accountancy, in Buenos Aires we listed Tango and BEJERMAN as Management Software and SAP as Database software. In Bogotá, the additional programs were: SIIGO, SAP, NOVASOFT and SISTEMA UNO. For Sales/ Commercial, in Buenos Aires we listed Maria Operative System and Fox and Fridman in Database software. In the case of Bogotá, none of the ads in this occupational category required additional software, so we did not listed any.

\subsection{Our Bank of CVs}

As indicated above, job vacancies were grouped into two occupational categories: Sales/Commercial and Administration/Accountancy. Two research assistants were assigned responsibility for each specific category. They were in charge of selecting the weekly vacancies, as well as the production, posting and supervision of the CVs sent. For each of these categories, we generate a database of fictitious CVs (half for Administration/Accountancy and half for Sales/Commercial) taken to be representative of the average job seeker.

In producing the CVs for each selected vacancy we intend to comply with the most competitive profile. For each ad, four CVs were chosen from the bank of CVs. ${ }^{7}$ In order to comply with the particular profile requested in the ad, features such as education, employment experience, and addresses were adjusted for each CV. Then, the CVs were uploaded in the websites considered in this study. Once uploaded to the website, every $\mathrm{CV}$ acquired the same layout. ${ }^{8}$ When a candidate applies for a job, the website sends the CV to the firm on his behalf.

Each set of four CVs is constructed so that its qualification levels (human capital) and employment experience are equivalent in order to ensure that the applicants are equally eligible for a given job.

\subsection{Ensuring the equivalence of Fictitious Applicants between Cells}

In each set of four fictitious CVs sent to each ad, we systematically varied sex and ICT skills level, so that we obtained one male and one female candidate for each of the possible ICT skill level. All other categories in the CV are assigned randomly, in the following way:

\footnotetext{
${ }^{7}$ See Appendix A for examples of the fictitious CVs.

${ }^{8}$ See Appendix B
} 
- Age: For each occupational category, the age of the applicants was set between 22 and 30 years of age in the case of Argentina and between 20 and 35 in Bogotá. These intervals were chosen following the mean age and standard deviation of the data set of real CVs surveyed for each city.

- ID Number: each fictitious applicant had a different ID number according to his age (and sex, in the case of Bogotá). In Argentina every ID number belongs to a real person. Therefore, in order not to compromise anyone, eight numbers were obtained under permission of the 'owners' to those IDs. As we had the availability of only eight ID numbers corresponding to individuals of 22, 23, 26 and 27 years old, we used real CVs from people of those ages to generate the fictitious CVs. These numbers were sufficient to create all the CVs needed without repeating any ID number. For Bogotá, ID numbers are assigned according to the region that issues the ID. Therefore, there is no straight forward link between the age and the ID number of a person. There is, however, a link between the ID number and the sex of the person. We did take care of that by assigning ID numbers that correspond to women to a fictitious female candidate and those that correspond to men to a fictitious male candidate. Overall 94 people agreed to sign a consent form allowing us to use their ID numbers.

- Names and Surnames: We used name frequency data by age range calculated from the actual CVs uploaded at the website for the corresponding city. The database for Buenos Aires consisted of $200 \mathrm{CVs}$ while for Bogotá we had $280 \mathrm{CVs}$ uploaded by real applicants aged between 17 and 32 that were looking for a job in the corresponding city. We calculated the most frequent names that appeared for man and woman. In the case of Bogotá we used the same procedure to generate the surnames as well. For Argentina, we used the most common surnames in the country according to an article published in an Argentinean newspaper and from World Names Profiler. ${ }^{9}$ Once we selected the most common/neutral names and surnames, they were randomly matched in order to avoid the use of a name belonging to a real person.

- E-mails: For each fictitious combination of name and surname we generated one email address, either at hotmail.com, gmail.com or yahoo.com.

- Neighborhoods: In order to facilitate the field work, the study is concentrated in the biggest and most populated metropolitan urban region in Argentina, Buenos Aires and also the most populated in Colombia, Bogotá. Buenos Aires is the capital, and largest city of Argentina, currently the second-largest metropolitan area in South America, after Sao Paulo. Buenos Aires is divided in four regions: North GBA, South GBA, West GBA and Capital Federal. Capital Federal is again divided in fifteen neighborhoods (Centros de Gestiones Personales Comunales, CGPC) and each region of GBA is also divided into several districts. We

\footnotetext{
${ }^{9}$ Herrera, Silvana El origen y la historia de los apellidos en Argentina, Diario Perfil, 2008. See Appendix D for more details.
} 
constructed fictitious residential areas based on the neighborhoods and districts of Buenos Aires. ${ }^{10}$ The randomized selection of the residential areas was done in the following way: for example, for a job vacancy located in Capital Federal, we choose at random four different neighborhoods, each corresponding to one of the four different resumes. The process of randomization was carried out without replacement.

Bogotá is the capital city of Colombia. According to the 2009 census, Bogotá has $8,566,926$ inhabitants in its metropolitan area (47.5\% of the population are male and $52.5 \%$ women), while the city houses about $7,362,520$. The neighborhoods of Bogotá are categorized in 6 different strata, which are related to the economic level of the population living there, being 1 the lowest and 6 the highest. Based on the information obtained in the Bogotá CVs' survey, we overall used 80 real addresses: for strata 1,2, 5 and 6 we used 10 real addresses for each of them and 20 for strata 3 and 4.

- Marital Status: Applicants in both categories aged between 22 and 23 were assigned the marital status Single, while the marital status of applicants aged between 26 and 27 was either Single or Married because in Argentina the individuals of these ages could be married or single with equal probability. In Colombia is not that unusual to get marry at a young age, therefore, the marital status of all fictitious applicants was randomized.

- Education: Following previous literature from Latin-America (Galiani and Sanguinetti, 2003; among others) we considered semi-skilled individuals as those with complete high school and skilled individuals with undergraduate degree ongoing. For all the undergraduate applicants we selected Universidad de Buenos Aires (UBA)- as the institutional education because it is the most representative of the population ${ }^{11}$ - and various universities from Colombia, being the source again the CV survey. On the other hand, the selection of the high schools for the semiskilled individuals as for the skilled ones was made according to the applicants neighborhood of residence. A bank of public high schools was constructed for this purpose. Using the official website of Capital Federal and the one of the Ministry of Education, we randomly selected public schools for each of the fifteen CGPC of Capital Federal and also for each of the districts of GBA. ${ }^{12}$ In Bogotá, high school quality is assessed yearly by the Colombian Institute to Promote Higher Education (ICFES, from the Spanish acronym Instituto Colombiano de Fomento a la Educacion Superior). ${ }^{13}$ The high school dataset used for the randomization process was built using the ICFES records for schools in Bogotá and considered

\footnotetext{
${ }^{10}$ See Appendix E

${ }^{11}$ According to the last Argentine Student Census (October 2008), Universidad de Buenos Aires (UBA) is the biggest argentine university, with 253,260 undergraduate students.

${ }^{12}$ See Appendix E

${ }^{13}$ All high school students that are about to graduate have to take the same exam, then the school receives a mark according to its students' performance.
} 
public and private schools of different quality. ${ }^{14}$

- Employment Experience: The employment experience of the applicants is equivalent within occupational categories but different between categories. We constructed a bank of employment experience for each occupational category from our pre-experiment CV survey. The descriptions were sufficiently altered to create distinct sets that would not be associated with real applicants, but the original overall content was maintained. Using the database of real CVs we found that the undergraduate applicants, who spend more time in the educational system, have fewer years of employment experience; meanwhile, the high school graduates have a longer track record in the labor market. ${ }^{15}$ Thus, the number of previous jobs was set to 2 for undergraduate applicants and to 4 for the high school graduates. Considering this, for each set of CVs we choose at random job experiences from the banks settled. During the experiment, when an ad required a particular job experience that was not available in our bank of resumes, we used the filters available in the website to find the experience that would better comply with the requirements (residence city, age, job experience, education) of that ad.

- Telephone Number: Each CV of the set of four sent out to a single ad had a unique cellphone number. Applicants in each sex/ICT skills cell were allocated the same phone number. This guaranteed that we could precisely track employer callbacks in each of these cells and ensured that recruiters did not encounter repeated phone numbers.

- Pay Expectations: The pay expectations, which generally had to be included in job applications, were also based on the information gathered on our CVs survey. We used the average pay level required for each category. So, each set of 4 CVs sent for a vacancy stated the same expected pay. For Bogotá this information was not required, therefore we selected the neutral option given by the job search engine, which was the 'to be negotiated' category.

- Languages: Following the results of our CVs survey, in Buenos Aires we selected advanced English knowledge for the undergraduate applicants, and basic English knowledge for the remaining ones for both occupational categories. For Bogotá we randomly varied the level of English among intermediate, basic and none, which were the levels identified in the survey.

- References: Giving a reference in each CV implies the creation of other fictitious identities (at least e-mail addresses and telephone numbers for those referenced). Since none of the ads asked this as a mandatory 'line' in the CV, and given that almost none of the CV surveyed included this feature, we left this information blank in our fictitious CVs.

\footnotetext{
${ }^{14}$ In the assessment each school receives an overall grade, which can be either: Very Inferior, Inferior, Low, Medium, High, Superior, Very Superior.

${ }^{15}$ See Appendix B
} 
This procedure left us with a bank of names, surnames, neighborhoods and high schools that we could assign to the template resumes when responding to the employment ads.

\subsection{Responding to Adds}

We eliminated any ad where applicants were asked to call or appear in person or where the sex of the applicant is markedly specified. For each ad, we use the bank of resumes to sample four resumes (two high-ICT skills and two low-ICT skills) that fit the job description and requirements as closely as possible. In some cases, we slightly altered the resumes to improve the quality of the match, such as by adding the knowledge of a specific software program or experience in a particular field. One of the men and one of the women resumes generated were then drawn at random to receive high ICT skills, the other women and men resumes received low-ICT skills.

In brief, four resumes were sent to each ad (i.e. employer). The first represents a male applicant with high ICT skills, while the second would be a male applicant with low ICT skills. The third represents a female applicant with high ICT skills; and, finally, the forth would be a female applicant with low ICT skills.

\section{The Data}

For the Buenos Aires case, the experiment started in October $19^{\text {th }}$ and lasted almost two months (until December $9^{\text {th }}$ ). On average, $60 \mathrm{CVs}$ were sent per day, with a total of 2,688 CVs sent to the two occupational categories (1,488 to Administration/Accountability and 1,200 to Sales/Commercial). We responded to approximately 675 ads for both occupational categories.

In Bogotá, the experiment started on November $20^{\text {th }} 2009$ and lasted until March $8^{\text {th }}$ 2010. The duration is longer than in the Buenos Aires case, because we had the downside part of the cycle that corresponds to December and January. CVs were sent to 2,076 ads in total (1,402 for Sales/ Commercial and 674 for Administration/Accountability). All the CVs were sent by e-mail through job-search websites.

\subsection{Descriptive Statistics}

In this section we analyze the descriptive statistics of the full experimental data. As shown in Table 1, the average callback response rate of the experiment was $8,57 \%$, while the e-mail response rate was only 3.1\% (see Appendix G, Tables G1a and G1b for the by country- disaggregated statistics). From the total number of CVs sent $(10,992)$ only 936 of them received callback. In addition, $23 \%$ of the ads or vacancies used in the experiment required some kind of ICT skill related to the job and $9.5 \%$ of those ads were high-lightened. With respect to education, we can see that $68.2 \%$ of the applicants are still pursuing undergraduate studies, while $3.8 \%$ have only completed high school. ${ }^{16}$

\footnotetext{
${ }^{16}$ Moreover, for both countries the distribution of the residential areas is concentrated in Capital Federal $(63.7 \%$ of the ads corresponds to this geographical area) and Bogotá (100\%) Note that the
} 
Table 1: Summary Statistics -LAC

\begin{tabular}{lcccc}
\hline Variable & Mean & Standard deviation & Maximum & Minimum \\
\hline Callback & 0.0857 & 0.2800 & 0 & 1 \\
E-mail & 0.0310 & 0.1733 & 0 & 1 \\
Age & 24,74 & 3,79 & 18 & 35 \\
Gender & 0.4990 & 0.5000 & 0 & 1 \\
Married & 0.3329 & 0.4879 & 0 & 1 \\
ICT Skill & 0.4991 & 0.5000 & 0 & 1 \\
ICT Required by the Ad & 0.2278 & 0.4194 & 0 & 1 \\
Undergraduate Ongoing & 0.6821 & 0.4656 & 0 & 1 \\
High School Graduated & 0.3178 & 0.4656 & 0 & 1 \\
Number of Observations $=\mathbf{1 0 9 2 2}$ & & & \\
\hline
\end{tabular}

Note: by-country tables are in Appendix G

Table 2 presents the number of CVs by occupational category or type of job. This table shows that the number of CVs sent was approximately the same in all the demographic cells. We sent around 1,700 CVs in each demographic sell of Sales/Commercial occupational category and 1,050 CVs in each demographic cell of Administration/Accountancy occupational category.

Table 2: Number of CVs sent by Occupational Category-LAC

\begin{tabular}{lcccc}
\hline & \multicolumn{2}{c}{$\begin{array}{c}\text { Administration/ } \\
\text { Accountability }\end{array}$} & \multicolumn{2}{c}{$\begin{array}{c}\text { Sales/ } \\
\text { Commercial }\end{array}$} \\
\hline High ICT Skills & 1,048 & 1,047 & 1,701 & 1,702 \\
Low ICT Skills & 1,046 & 1,045 & 1,701 & 1,702 \\
\hline Total & 2,094 & 2,092 & 3,402 & 3,404 \\
\hline Note: by-country tables are in Appendix G
\end{tabular}

Table 3 shows the number of callbacks by demographic cell and occupational category. ${ }^{17}$ In the case of Administration/Accountancy, we can see that those individuals with high ICT skills are called more than those with low ICT skills, while in the other occupational category the difference is not as large. On the other hand, it seems that females are called more often than males in both categories.

Tables 4 and 5 show the differences in the callback rate by gender and ICT skills, respectively. In Table 4 we can see that in the occupational category Administration/Accountancy, females are called $8.19 \%$ more than males and this difference is significant at $1 \%$ level of significance. For the Sales/Commercial occupational category there

resumes were also sent to the GBA area, 9\% to North GBA, 3.4\% to South GBA and 3.2\% to West GBA. The proportion of CVs sent to the GBA area is much lower compared to Capital Federal, but this is due to the fact that vacancies for this areas are much less than those of Capital Federal (9.22\% of the vacancies correspond to North GBA, $1.19 \%$ to South GBA and $3.42 \%$ to West GBA).

${ }^{17}$ It is important to note that the average callback rate by week was maintained relatively stable during all the experiment. 
Table 3: Number of Callbacks by Occupational Category-LAC

\begin{tabular}{lcccc}
\hline & \multicolumn{2}{c}{ Administration/ } & \multicolumn{2}{c}{ Sales/ } \\
& \multicolumn{2}{c}{ Accountability } & \multicolumn{2}{c}{ Commercial } \\
\hline & Male & Female & Male & Female \\
High ICT Skills & 82 & 104 & 140 & 168 \\
Low ICT Skills & 65 & 92 & 145 & 146 \\
\hline Total & 147 & 196 & 285 & 314 \\
\hline Note: by-country tables are in Appendix G
\end{tabular}

is no gender difference in the response rate (either by email or phone).

On the other hand, for Administration/Accountancy, applicants with high ICT skills are called for an interview $1.4 \%$ more than applicants with low ICT skills, and this difference is significant at the $10 \%$ level. However, for Sales/Commercial, applicants with high ICT skills are called almost as much as those with low ICT skills.

Table 4: Differences in Callback Rate by Gender

\begin{tabular}{lccc}
\hline & Male & Female & Difference \\
\hline Administration/Accountability & 0.07 & 0.094 & 0.0819 \\
& $(0.0056)$ & $(0.0064)$ & $(0.0042)^{* * *}$ \\
Sales/Commercial & 0.084 & 0.092 & 0.0085 \\
& $(0.0047)$ & $(0.0050)$ & $(0.0069)$ \\
\hline
\end{tabular}

Note: by-country tables are in Appendix G

Table 5: Differences in Callback Rate by ICT Skills - LAC

\begin{tabular}{lccc}
\hline & High ICT Skill & Low ICT Skill & Difference \\
\hline Administration/Accountability & 0.089 & 0.075 & -0.0138 \\
& $(0.0062)$ & $(0.0058)$ & $(0.0085)^{*}$ \\
Sales/Commercial & 0.0908 & 0.0854 & -0.005 \\
& $(0.0049)$ & $(0.0047)$ & $(0.0069)$ \\
\hline
\end{tabular}

Note: by-country tables are in Appendix G

\section{Results}

In this section we present the regression results for the effect of ICT skills on the probability of getting a callback. As the data available for the study is cross-sectional, we always include a set of control variables. These control variables include applicant's characteristics such as age, gender, marital status, education, dummies for residential area and occupational category. Given its relevance for our analysis, we also include a dummy variable for whether the ad required ICT skills.

Tables 6 and 7 show results of OLS and Probit regressions, respectively, where the dependent variable takes value 1 if the applicant has been called after sending the CV 
Table 6: Estimates of Receiving a Callback (cluster by employer)

\begin{tabular}{|c|c|c|c|}
\hline Callback & & OLS & \\
\hline Variable & 1 & 2 & 3 \\
\hline ICT Skill & $\begin{array}{c}0.00963^{* *} \\
(0.00443)\end{array}$ & $\begin{array}{l}0.00726^{*} \\
(0.00432)\end{array}$ & $\begin{array}{c}0.00726 \\
(0.00471)\end{array}$ \\
\hline Age & & $\begin{array}{c}-0.00875^{* * *} \\
(0.00207)\end{array}$ & $\begin{array}{c}-0.0109^{* * *} \\
(0.00247)\end{array}$ \\
\hline Gender & & $\begin{array}{l}-0.0170^{*} \\
(0.00945)\end{array}$ & $\begin{array}{l}-0.0168^{*} \\
(0.00864)\end{array}$ \\
\hline Marital Status & & $\begin{array}{c}-0.0191 * \\
(0.0103)\end{array}$ & $\begin{array}{c}-0.0250^{* *} \\
(0.0103)\end{array}$ \\
\hline ICT Required by the Ad & & $\begin{array}{l}0.00545 \\
(0.0130)\end{array}$ & $\begin{array}{l}0.00158 \\
(0.0165)\end{array}$ \\
\hline Undergraduate Ongoing & & $\begin{array}{l}-0.00520 \\
(0.0116)\end{array}$ & $\begin{array}{l}0.00191 \\
(0.0130)\end{array}$ \\
\hline Highlighted Ad & & $\begin{array}{c}0.0606 \\
(0.0481)\end{array}$ & $\begin{array}{c}0.0621 \\
(0.0478)\end{array}$ \\
\hline Webpage & & $\begin{array}{c}0.0241^{* * *} \\
(0.00746)\end{array}$ & $\begin{array}{r}0.0237^{* * * *} \\
(0.00752)\end{array}$ \\
\hline Argentina & & $\begin{array}{l}-0.0412 \\
(0.0452)\end{array}$ & $\begin{array}{l}-0.0372 \\
(0.0447)\end{array}$ \\
\hline Occupational Category & & $\begin{array}{l}-0.0194 \\
(0.0152)\end{array}$ & $\begin{array}{c}-0.00379 \\
(0.0168)\end{array}$ \\
\hline Constant & $\begin{array}{c}0.107^{* * *} \\
(0.0147) \\
\end{array}$ & $\begin{array}{c}0.301 * * * \\
(0.0591) \\
\end{array}$ & $\begin{array}{c}0.348^{* * *} \\
(0.0679) \\
\end{array}$ \\
\hline Residential area fixed effect & yes & yes & yes \\
\hline Observations & 8,235 & 8,235 & 8,235 \\
\hline
\end{tabular}

Note: Robust clustered standard errors at the Employer level are in parentheses for columns. Column 1 is Ols-only with cluster Employer; Column 2 is Ols-full with cluster Employer; Column 3 is Ols- full with cluster Employer and weight. Colombia is base category.

* Statistically different from zero at the $10 \%$ level of significance;

$* *$ Statistically different from zero at the $5 \%$,

*** Statistically different from zero at the $1 \%$ level of significance.

and 0 otherwise. Additionally, the main independent variable of interest is also binary taking the value of 1 if the applicant has high ICT skills and 0 otherwise.

Huber-White standard errors are reported in parentheses to account for heteroskedasticity and are clustered at the employer-level in all specifications. 18 The regression reported in the first column only includes the ICT skills dummy; the second shows the specifications with all the controls; while the third one adds a proportional weight given that Argentina had fewer observations than Colombia. ${ }^{19}$

In the first two specifications, the coefficient (marginal effect, for the Probit regression) of the variable of interest (ICT skills) is statistically significant and very stable across specifications. However, this is only marginally significant (at 15\%) for the

\footnotetext{
${ }^{18}$ Clustering at the regional level gives similar results, which are available upon request.

${ }^{19}$ The weight for Colombia is 0.5, while for Argentina is 1 .
} 
Table 7: Estimates of Receiving a Callback (cluster by employer)

\begin{tabular}{lccc}
\hline Callback & \multicolumn{3}{c}{ Probit } \\
\hline Variable & 4 & 5 & 6 \\
\hline ICT Skill & $0.00963^{* *}$ & $0.00708^{*}$ & 0.00685 \\
Age & $(0.00442)$ & $(0.00412)$ & $(0.00457)$ \\
& & $-0.0106^{* * *}$ & $-0.0135^{* * *}$ \\
Gender & $(0.00190)$ & $(0.00217)$ \\
& $-0.0161^{*}$ & $-0.0161^{* *}$ \\
Marital Status & $(0.00827)$ & $(0.00767)$ \\
ICT Required by the Ad & $-0.0191^{* *}$ & $-0.0233^{* *}$ \\
& & $(0.00901)$ & $(0.00981)$ \\
Undergraduate Ongoing & 0.00431 & 0.000533 \\
Highlighted Ad & $(0.0124)$ & $(0.0153)$ \\
Webpage & 0.00364 & 0.0100 \\
& & $(0.0102)$ & $(0.0122)$ \\
Argentina & 0.0425 & 0.0481 \\
& & $(0.0355)$ & $(0.0383)$ \\
Occupational Category & $0.0254^{* * *}$ & $0.0277^{* * *}$ \\
& & $(0.00782)$ & $(0.00868)$ \\
\hline Residential area fixed effect & -0.0331 & -0.0372 \\
Observations & yes & $(0.0542)$ & $(0.0640)$ \\
\hline Note: Robur & $-0.0289^{*}$ & -0.0155 \\
\end{tabular}

Note: Robust clustered standard errors at the Employer level are in parentheses. Column 4 is Probit-only with cluster Employer; Column 5 is; Probit-full with cluster Employer; Column 6 is Probit- full with cluster

Employer and weight. Colombia is base category.

* Statistically different from zero at the $10 \%$ level of significance;

** Statistically different from zero at the $5 \%$,

*** Statistically different from zero at the $1 \%$ level of significance.

weighted regression. The probability of obtaining a callback rate is about 1 percentage point higher for those who have high ICT skills. Additionally, age, gender, marital status, webpage visited, occupation and some of Buenos Aires residential areas are statistically significant and with the expected sign.

These regressions suggest that older applicants are less likely of getting a callback compared to younger applicants; married applicants are also less likely to be called, as well as male applicants applicants. In addition, the dummy variable for the Northern metropolitan area of Buenos Aires (GBA North) show a positive effect on callbacks, which suggest that people who live there are more likely to be called for an interview than those who live in other areas in Buenos Aires, and also relatively more than those who live in Bogotá. 20

\footnotetext{
${ }^{20}$ The dummy variable for 'Capital Federal' is significant in the OLS regressions, suggesting that under the linear specification, the applicants that live there are, on average, more likely to be called for an interview.
} 
Finally, it is interesting to note that the fact that ICT skills were mentioned in the ad is not significant in explaining the callback rate. This suggests that having ICT skills in the resume is relevant (as shown above), even when the ad does not specifically requires it.

In Table 8 we present estimations within each occupational category. For each category, the first column shows Probit marginal effects for the specification with all the controls, while the second column show the Probit marginal effects for the weighted regression. Our main variable of interest, ICT skills, is only significant for Administration/Accountancy category (as well as Gender). Marital Status is only significant for the Sales/Commercial category, where married candidates are less likely to be called back. On the other hand, residents in Capital Federal are on average more likely to be called for an interview for the Sales/Commercial category.

Table 8: Probit Estimates of Receiving a Callback by Occupational Category

\begin{tabular}{lcccc}
\hline Callback & \multicolumn{2}{c}{$\begin{array}{c}\text { Administration/ } \\
\text { Accountability }\end{array}$} & \multicolumn{2}{c}{$\begin{array}{c}\text { Sales/ } \\
\text { Commercial }\end{array}$} \\
\hline Variable & 1 & 2 & 3 & 4 \\
\hline ICT Skill & $0.0132^{* *}$ & $0.0158^{* *}$ & 0.00509 & 0.00231 \\
Age & $(0.00600)$ & $(0.00733)$ & $(0.00610)$ & $(0.00627)$ \\
& $-0.00704^{* * *}$ & $-0.0103^{* * *}$ & $-0.00821^{* * *}$ & $-0.0102^{* * *}$ \\
Gender & $(0.00225)$ & $(0.00321)$ & $(0.00217)$ & $(0.00263)$ \\
& $-0.0259^{* * *}$ & $-0.0289^{* * *}$ & -0.00683 & -0.00348 \\
Marital Status & $(0.00758)$ & $(0.00918)$ & $(0.0109)$ & $(0.0101)$ \\
& -0.0152 & -0.0201 & $-0.0237^{*}$ & $-0.0303^{* *}$ \\
ICT Required by the Ad & $(0.0106)$ & $(0.0148)$ & $(0.0136)$ & $(0.0142)$ \\
& -0.00445 & -0.00856 & 0.0221 & 0.0224 \\
Undergraduate Ongoing & $(0.0138)$ & $(0.0188)$ & $(0.0230)$ & $(0.0251)$ \\
Highlighted Ad & 0.0381 & $0.0596^{*}$ & $-0.0439^{* * *}$ & $-0.0435^{* * *}$ \\
Webpage & $(0.0274)$ & $(0.0324)$ & $(0.0133)$ & $(0.0141)$ \\
& 0.0456 & 0.0569 & 0.0393 & 0.0405 \\
Argentina & $(0.0400)$ & $(0.0487)$ & $(0.0571)$ & $(0.0580)$ \\
& -0.0120 & -0.0158 & $0.0322^{* * *}$ & $0.0326^{* * *}$ \\
\hline Residential area fixed effect & $(0.0155)$ & $(0.0199)$ & $(0.00936)$ & $(0.00964)$ \\
\hline Observations & 0.101 & 0.105 & $-0.118^{* * *}$ & $-0.136^{* * *}$ \\
\hline Note: Robs & $(0.0941)$ & $(0.0868)$ & $(0.0320)$ & $(0.0459)$ \\
\hline
\end{tabular}

Note: Robust clustered standard errors at the Employer level are in parentheses.

Column 1 and 3 are Probit-full with cluster Employer; Column 2 and 4 are Probit- full

with cluster Employer and weight. Colombia is base category.

* Statistically different from zero at the $10 \%$ level of significance;

** Statistically different from zero at the $5 \%$,

*** Statistically different from zero at the $1 \%$ level of significance.

An interesting result is that, those applicants that are undergraduate students are, 
on average, significantly more successful but only in the Administration/Accountancy category. On the contrary, in the Sales/Commercial category, these applicants are less likely to be called for an interview than the ones that have only completed high school education. ${ }^{21}$

Finally, Table 9 includes the interaction of ICT skill with the dummy variable country, which takes value 1 for Argentina and 0 for Colombia. Results remain as those observed for the same specification without the interaction (shown in columns 5 and 6 of Table ??) However, the interaction shows that the effect of having ICT skills is not significant at standard levels in Argentina (although it is still significant at the 18\% level), showing that different labor markets might value differently the acquisition of ICT skills.

\section{Conclusion}

This paper contributes to the literature on labor markets in a developing country, particularly in what refers to how ICT skills affect employment possibilities. We use an experimental approach to identify for the first time the effect of different levels of ICT skills on the likelihood of being called for a job interview in two Latin-American cities.

A simple descriptive analysis of our data and the regression analysis suggest that having some knowledge of informatics tools could generate higher employment opportunities, supporting previous (though less rigorous) literature. The quantitative effect of having ICT skills in the resume can increase the probability of receiving a callback by around 1 percent. This effect is much stronger in Bogotá than in Buenos Aires, showing that different labor markets might value differently the acquisition of ICT skills. We intend to explore these country differences further in future research. Of course, one important limitation of our results is that we are only analyzing one step in the complex process behind a hiring decision, namely the callback for an interview.

\footnotetext{
${ }^{21}$ These results are in line with the findings obtained from the previous investigation for the construction of the CVs. (Bertrand and Mullainathan, 2004, Bravo et al., 2008).
} 
Table 9: Probit Estimates of Receiving a Callback (ictskill x country)

\begin{tabular}{|c|c|}
\hline Callback & Probit \\
\hline \multicolumn{2}{|l|}{ Variable } \\
\hline ICT Skill & $\begin{array}{c}0.0103^{*} \\
(0.00592)\end{array}$ \\
\hline ICT Skill x Country & $\begin{array}{l}-0.00433 \\
(0.00801)\end{array}$ \\
\hline Age & $\begin{array}{c}-0.0105^{* * * *} \\
(0.00196)\end{array}$ \\
\hline Gender & $\begin{array}{c}-0.0167^{* *} \\
(0.00824)\end{array}$ \\
\hline Marital Status & $\begin{array}{c}-0.0207^{* *} \\
(0.00810)\end{array}$ \\
\hline ICT Required by the Ad & $\begin{array}{l}0.00402 \\
(0.0124)\end{array}$ \\
\hline Undergraduate Ongoing & $\begin{array}{l}0.00463 \\
(0.0105)\end{array}$ \\
\hline Highlighted Ad & $\begin{array}{c}0.0423 \\
(0.0354)\end{array}$ \\
\hline BA-Capital Federal & $\begin{array}{c}0.0974 \\
(0.0773)\end{array}$ \\
\hline GBA North & $\begin{array}{l}0.241^{*} \\
(0.137)\end{array}$ \\
\hline GBA West & $\begin{array}{c}0.0794 \\
(0.102)\end{array}$ \\
\hline Bogota Center & $\begin{array}{l}0.00592 \\
(0.0168)\end{array}$ \\
\hline Bogota North & $\begin{array}{c}-0.0160 \\
(0.0137)\end{array}$ \\
\hline Bogota East & $\begin{array}{l}0.00756 \\
(0.0143)\end{array}$ \\
\hline Bogota West & $\begin{array}{c}0.00207 \\
(0.0133)\end{array}$ \\
\hline Webpage & $\begin{array}{c}0.0255^{* * *} \\
(0.00779)\end{array}$ \\
\hline Argentina & $\begin{array}{l}-0.0322 \\
(0.0547)\end{array}$ \\
\hline Occupational Category & $\begin{array}{c}-0.0291^{* *} \\
(0.0147)\end{array}$ \\
\hline Observations & 8,235 \\
\hline
\end{tabular}

Note: Robust clustered standard errors at the Employer level are in parentheses.

* Statistically different from zero at the $10 \%$ level of significance;

** Statistically different from zero at the $5 \%$,

$* * *$ Statistically different from zero at the $1 \%$ level of significance.

\section{References}

Altonji, J. G. and Blank, R. M. (1999). Race and gender in the labor market, in O. Ashenfelter and D. Card (eds), Handbook of Labor Economics, Vol. 3 of Handbook 
of Labor Economics, Elsevier, chapter 48, pp. 3143-3259.

Bertrand, M. and Mullainathan, S. (2004). Are emily and greg more employable than lakisha and jamal? a field experiment on labor market discrimination, American Economic Review 94(4): 991-1013.

URL: http://econpapers.repec.org/RePEc:aea:aecrev:v:94:y:2004:i:4:p:991-1013

Blank, R., M. D. and Citro, C. (2004). Measuring Racial Discrimination: Panel on Methods for Assessing Discrimination., National Academies Press.

Bravo, D., Sanhueza, C. and Urzua, S. (2008). Estudio experimental de discriminacin de mercado de trabajo: Sexo, clase social y vecindario en chile, (3243).

URL: http://ideas.repec.org/p/idb/wpaper/3243.html

Chapple, K. (2006). Moving Beyond the Divide: Workforce Development and Upward Mobility in Information Technology, Policylink and The institute of urban and regional development (IURD).

David Castillo, Jordi Vilaseca, E. S. and Valls, N. (2008). E-learning and labour market: Wage-premium analysis, Revista de Universidad y Sociedad del conocimiento .

Heckman, J. J. (1998). Detecting discrimination, The Journal of Economic Perspectives 12(2): pp. 101-116.

URL: $h t t p: / / w w w . j s t o r . o r g / s t a b l e / 2646964$

Hernn Ruffo, P. N. and Brassiolo, P. (2006). Uso y adopcin de tecnologa informtica en el mercado laboral de argentina, Instituto de Estudios sobre la Realidad Argentina y Latinoamrica .

Jacinto, C. and Lusquios, C. (2007). Serie de aprendizaje no.3: Jvenes y la calidad de los empleos: Resultados del programa entra21, Fundacin Internacional para la Juventud

Karen Mossberger, C. J. T. and McNeal, R. S. (2008). Digital citizenship : the internet, society, and participation., Cambridge, Mass: MIT Press.

Lpez-Bassols, V. (2002). Ict skills and employment, OECD Science, Technology and Industry Working Papers 2002/10, OECD, Directorate for Science, Technology and Industry.

URL: http://econpapers.repec.org/RePEc:oec:stiaaa:2002/10-en

Riach, P. A. and Rich, J. (2002). Field experiments of discrimination in the market place, Economic Journal 112(483): 480-518.

URL: http://ideas.repec.org/a/ecj/econjl/v112y2002ił83p480-518.html

Siegelman, P. and Heckman, J. (1993). The urban institute audit studies: Their methods and findings. 